\title{
Physico-chemical Quality of Soils under Cocoa Farm in Koffikro-Affema (Aboisso) in South-East of Côte d'Ivoire
}

\author{
Yao Kouman Nestor Kouakou, Jéremie Gala Bi Trazié, and Albert Yao-Kouamé
}

\section{ABSTRACT}

The study was conducted in Koffikro-Affema village located in the SouthEast of Côte d'Ivoire to assess the morpho-physical and chemical quality of soils under cocoa farm, for the management of early degradation of orchards. Representative soil samples were taken by horizon under degraded cocoa farms after a morpho-pedological characterisation. These samples were then analysed in the laboratory for fertility parameters. The results indicate that the cocoa farms have a high rate of degradation and the study made it possible to identify the soil characteristics associated not only with the degradation of cocoa trees, but also with the drop in yield. These are the rate of coarse grains greater than $50 \%$, the low organic matter content (less than $3.5 \%)$, a very slow rate of mineralisation $(\mathrm{C} / \mathrm{N}>12)$, poor internal drainage and the acidic $\mathrm{pH}$ of the soil (4.4-5.5). The soils surveyed are highly desaturated to moderately saturated and the main characteristics of the absorbing complex indicate that they are unfavourable for cocoa. Indeed, these soils are deficient in $\mathrm{K}^{+}(<0.2 \mathrm{cmol} / \mathrm{kg}), \mathrm{Ca}^{2+}$ (between 5.1 and $11.41 \mathrm{cmol} / \mathrm{Kg})$ and assimilable Nitrogen $(<0.2 \mathrm{cmol} / \mathrm{Kg})$. Similarly, the $\mathrm{Mg}^{2+/} \mathrm{K}^{+}$ratio of less than 3 shows that they are magnesium deficient. The results also revealed an influence of the topographical position on the degradation of cocoa trees with, on the upper and middle slopes, strongly gravelly and poorly drained horizons, associated with the degradation of cocoa trees. On the other hand, on the lower slopes, these soils are deep, not gravelly, with good growth of cocoa trees and low yields.

Keywords: Cocoa tree, Côte d'Ivoire, Degradation, Fertility, Koffikro-Afféma, Morpho-pedology.

\section{INTRODUCTION}

Côte d'Ivoire is known for having a cocoa orchard representing more than $75 \%$ of the area under cultivation [1] over a surface area of nearly $2,300,000$ ha [2], making it the world's leading producer and exporter of cocoa beans [3]. However, for some years now, the actors in this sector have been confronted with the scarcity of cultivable land and have rushed to buy any piece of land they could find without really taking into account the suitability of the soil for cocoa farming. It is accepted that the choice of soil is decisive from a physical, chemical and physico-chemical point of view, not only for the success of replanting, but also and above all for the sustainability of the farms [4]-[6].

The best performances in cocoa production in Côte d'Ivoire have been obtained in the eastern and central-western production regions. However, for more than two decades, while the creation of cocoa plantations has taken off considerably in the South-West [7], the South-East zone, which has traditionally been more productive [8], has been subjected to a deterioration of the orchards on certain farms. This is the case, for example, in Koffikro-Affema, a village
Submitted : November 04, 2021

Published : December 12, 2021

ISSN: $2684-1827$

DOI: 10.24018 /ejfood.2021.3.6.411

Yao Kouman Nestor Kouakou*

University Félix Houphouet-Boigny, UFR STRM, Abidjan, Côte d'Ivoire.

(e-mail: nestkoya ${ }^{\circledR}$ yahoo.fr) Jéremie Gala Bi Trazié

University Félix Houphouet-Boigny, UFR STRM, Abidjan, Côte d'Ivoire.

(e-mail: gala_trazie@yahoo.fr) Albert Yao-Kouamé

University Félix Houphouet-Boigny, UFR STRM, Abidjan, Côte d'Ivoire.

(e-mail: yaokouamealbert53@gmail.com)

*Corresponding Author located in the region of Aboisso in the south-east of Côte d'Ivoire, where the cocoa farms, after only 14 years of operation, are experiencing a significant drop in production, thus causing enormous difficulties for the farmers in the area. Compared to the orchards in the Central-Western region of Côte d'Ivoire, cocoa plantations in the Central-Western region generally reach 30 years of operation [9], [10], which is the opposite of Koffikro-Affema.

It therefore seems judicious to investigate the causes of the early degradation of cocoa orchards from a pedological point of view in order to provide solutions, if possible.

\section{Materials Et Methods}

\section{A. Characteristics of the Study Site}

\section{1) Geographic setting}

The village of Koffikro-Affema is located in the department of Aboisso in south-eastern Côte d'Ivoire, $16 \mathrm{~km}$ from the town of Maferé, between longitudes $5^{\circ} 9$ and $6^{\circ} 10$ $\mathrm{W}$ and latitudes $4^{\circ} 9$ and $5^{\circ} 10 \mathrm{~N}$ (Fig. 1). 


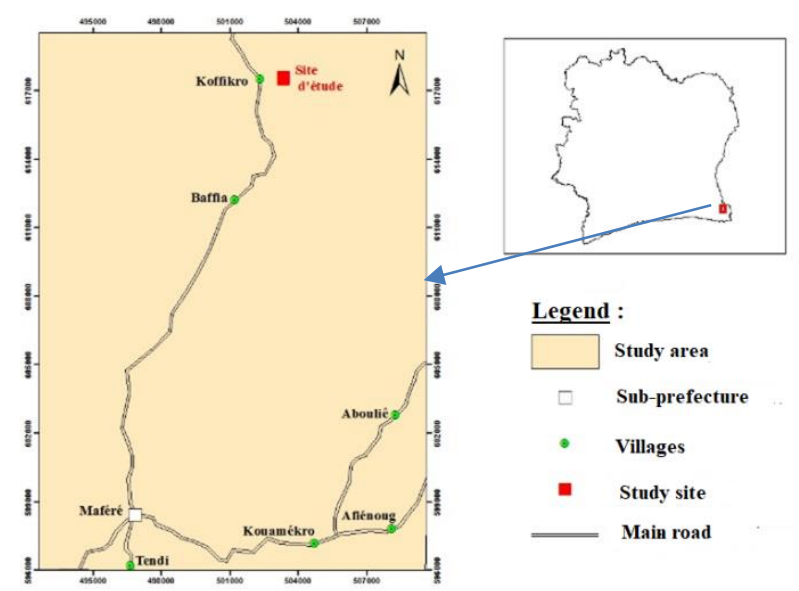

Fig. 1. Study site location.

\section{2) Relief and hydrography}

The environment brings together a diversity of geomorphological landscapes. It is very uneven in the northeast (Ayamé and Bianouan) and in the east (Maféré). In the north, a plateau and a plain alternate, shaped by the shale bedrock debris. The plateau is traversed by a dense and structured hydrographic network with rare topographical accidents. Apart from a few armour-clad hills, the gradients on this relief are moderate. The monotonous interior plain has lower gradients than the plateau [11]. The department of Aboisso is drained by a main river, the Bia, which crosses it from north to south and is watered by numerous rivers, namely the tributaries of the Bia and the Tanoé [12].

\section{3) Climate and vegetation}

The department of Aboisso benefits from a hot and rainy equatorial climate (Attiéen climate). This climate is characterised by abundant rainfall, with an average height of around $1,500 \mathrm{~mm}$ over the last ten years [12]. It is characterised by high atmospheric humidity ( $85 \%$ per year), high but not excessive temperatures $\left(25^{\circ} \mathrm{C}\right.$ on average), constant throughout the year, and low temperature ranges of less than $5^{\circ} \mathrm{C}$. The duration of sunshine varies between 1500 and 2000 hours per year. The rainfall regime is bimodal with two periods of rainfall and two periods of low rainfall called dry seasons [13].

The vegetation consists of dense evergreen forests and hydromorphic formations [14], coupled with vast agricultural areas composed of cocoa, coffee, oil palm and rubber trees.

\section{4) Geological and soil context}

At the geological level, the formations encountered can be grouped into two main groups: metavulcanites and metasediments [15]. These groups are essentially dominated by chlorite schists and tuffaceous schists. Intrusions of granites, diorites, metatonalites, metagabbros and metadolerites are observed. The south-western part of the Aboisso district is covered by a thin sedimentary layer made up of sand, clay and ferruginous sandstone known as "high plateau".

The soils of the Aboisso department belong to the ferralsol group, which are strongly leached under heavy rainfall. These soils remain of poor chemical quality, although generally deep [12]. They include Ferralsols on eruptive and metamorphic rocks (granite, schist, and basic rocks), with good water retention, suitable for perennial and annual crops (plantain, food crops, oil palm, coffee and cocoa); ferralsols on tertiary sands, of poor quality at great depths, allowing the cultivation of coffee, cocoa, oil palm and pineapple; soils developed on quaternary sands on which only coconut cultivation is feasible; hydromorphic soils that are much less extensive.

\section{B. Study Methods}

\section{1) Choice of plot of land}

The choice of the plot of land was based on criteria such as the age of the orchards, the state of degradation of the cocoa trees, the good follow-up of the orchard maintenance protocol, and the topographical position. Thus, a plot of 2 ha was selected where the orchards are 14 years old for a planting density of about 1300 trees per hectare, i.e., a total of 2600 trees. The orchards are $3 \times 2.5 \mathrm{~m}$ in size and in a markedly degraded state.

\section{2) Morpho-pedological characterisation}

The study of the plot's soils was carried out by setting up a toposequence along the $\mathrm{N} 184^{\circ}$ direction, respecting the standards of a system from the top to the bottom of the slope as defined by [16]. Five (5) soil pits, each $120 \mathrm{~cm}$ deep and noted from the top to the bottom of the slope, respectively P1, P2, P3, P4 and P5, were opened at every $50 \mathrm{~m}$, in accordance with the observation scale (1/5000).

The pits were described considering data on the physical environment (slope, topographic position, bedrock), on the horizons (thickness, colour, moisture, organic matter content, texture, percentage of coarse elements, structure, cohesion, porosity, rooting, root orientation, drainage class, clearness and shape of horizon boundaries) according to the guidelines of [17].

Texture was defined by the tactile field method and the nature and proportion of coarse elements. Internal drainage was assessed from the colour of the soil and the soil type was identified according to the WRB classification [18]. A total of eighteen (18) samples were described and collected, representative of the pit horizons, including four (4) in each of the pits P1, P2, P3 and P4 and two (2) in the P5 pit. In addition to these 18 samples, a composite auger sample at a depth of $0-20 \mathrm{~cm}$ was taken in the vicinity of each pit.

\section{3) Evaluation of the condition of cocoa trees}

Around each soil pit, a square mesh of fifty (50) meters side centered on the profile was formed to assess the condition of the cocoa trees. Thus, the cocoa trees described as being in good condition have mostly healthy pods with good vegetative condition where the leaves do not show signs of water deficiency and the tree canopy is generally well developed (Fig. 2).

On the other hand, the cocoa trees described as degraded have a more or less pronounced aspect of senescence, with mostly rotten pods and a poor vegetative state with leaves showing signs of water deficiency (Fig. 3). From these two criteria, the number of degraded cocoa trees and the number of non-degraded cocoa trees were evaluated to estimate the rate of degradation of the plot land. In total, three hundred and twenty (320) cocoa trees were described on the first four (4) topographical positions, namely the upper slope, the middle slope, the upper $1 / 3$ of the lower slope and the lower $1 / 3$ of 
the lower slope. One hundred and seventy (170) cocoa trees were described in the lowlands.

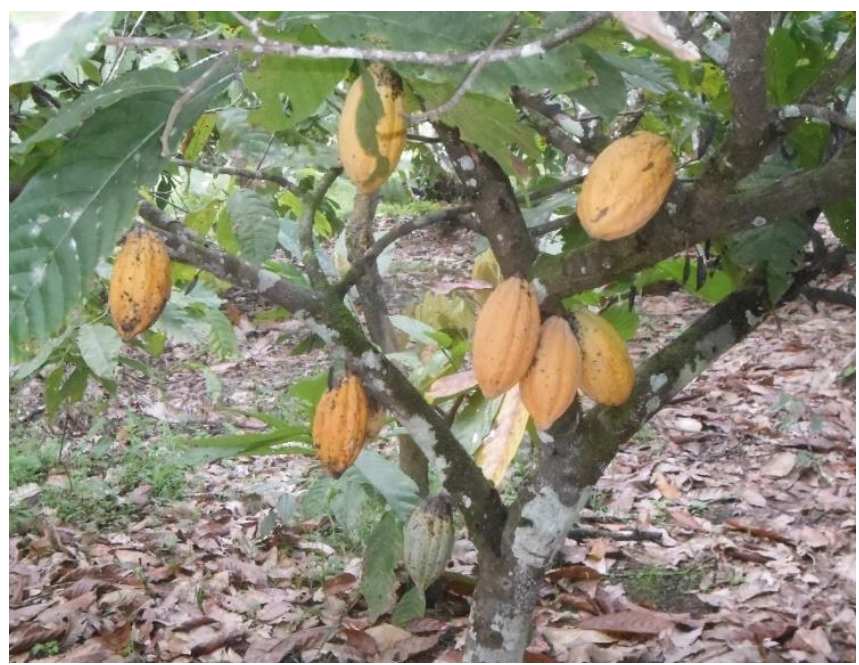

Fig. 2. Cocoa tree in good condition.
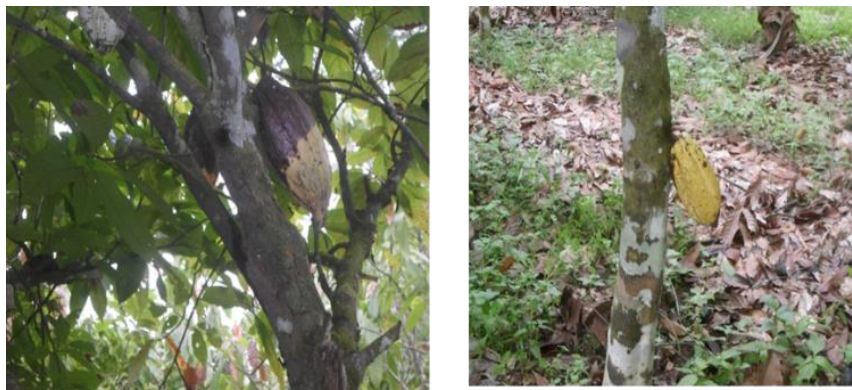

Fig. 3. Degraded cocoa trees in the study plot.

\section{4) Processing and analysis of samples}

The eighteen (18) samples taken were sent to the Pedology laboratory of the University Félix Houphouët-Boigny in Abidjan (Côte d'Ivoire) and dried in the shade in the open air for three days. They were then sieved using a $2 \mathrm{~mm}$ diameter sieve and packed in plastic bags.

A portion of each of the 18 samples was sent to the Geomaterials laboratory of the Université Félix HouphouëtBoigny for determination of particle size by the Robinson pipette method and of $\mathrm{pH}$. The five (5) samples taken from the $0-20 \mathrm{~cm}$ horizons were processed in the soil analysis laboratory of the Ecole Supérieure d'Agronomie de l'Institut National Polytechnique Houphouët-Boigny de Yamoussoukro (I.N.P.H.B.) for the determination of nitrogen, exchangeable bases $\left(\mathrm{K}^{+}, \mathrm{Mg}^{2+}, \mathrm{Ca}^{2+}\right)$, cation exchange capacity (CEC), organic carbon, $\mathrm{pH}$ of $\mathrm{H}_{2} \mathrm{O}$ and $\mathrm{pH}$ of $\mathrm{KCl}$.

The measurement of $\mathrm{pH}$ of $\mathrm{H}_{2} \mathrm{O}$ (effective acidity) and $\mathrm{pH}$ of $\mathrm{KCl}$ (reserve acidity) of the soil samples was obtained by the electrometric method using a $\mathrm{pH}$ meter with a glass electrode. This determination was carried out on different samples, in a soil/solution ratio of 1/2.5 and in triplicates [19].

Total organic carbon was determined by the method of Walkley and Black [20], using oxidation in a mixture of potassium dichromate and sulphuric acid, while total nitrogen (total $\mathrm{N}$ ) was determined by the Kjeldahl method [21]. The organic matter content was calculated by multiplying the carbon value obtained by 1.72 .
The CEC was determined by the Metson method (1956) and the determination of exchangeable bases was carried out by fully saturating the adsorbent complex with a monovalent cation $\mathrm{NH}^{4+}$ (ammonium acetate buffered $\mathrm{pH} 7$ ). The excess of this cation was then removed by washing with ethyl alcohol and determining the $\mathrm{NH}^{4+}$ by distillation and titration The saturation rate of the adsorbent complex (V) was determined by the ratio of cation exchange capacity to the sum of exchangeable bases, multiplied by one hundred (100).

\section{5) Statistical analysis of the data}

The different data obtained from the laboratory analyses were processed with the S XLSTAT 2014 software to establish correlations between the physical and chemical parameters. The variables were estimated at $\mathrm{P}<0.05$ according to Pearson's correlations.

\section{RESULTS}

\section{A. Soil Morphology}

The soils described are Cambisols, especially for profiles P1, P2, P3 and P4. Profile P5, on the other hand, is a Gleysol (Fig. 4 to 8 ).

The soils on the upper and middle slopes have similar morphological characteristics. They are generally brown (7.5YR 4/4 to 7.5YR 4/6) in the first horizons, with a sandyclay-silt texture with more than $50 \%$ coarse elements. Drainage is average. From $40 \mathrm{~cm}$, the texture is sandy-clay with more than $50 \%$ of coarse grains (quartz and ferruginous concretions) with poor drainage.

In the surface layer of the lower slope soils, the colour varies from dark grey (10YR3/2) to dark greyish brown (10YR 4/2) with a sandy-clay texture. In contrast, in the deeper horizons, the soils range in colour from brownish yellow $(7.5 \mathrm{YR} 6 / 6)$ to reddish yellow $(7.5 \mathrm{YR} 7 / 8)$ with a coarse element content of over $50 \%$ and good drainage.

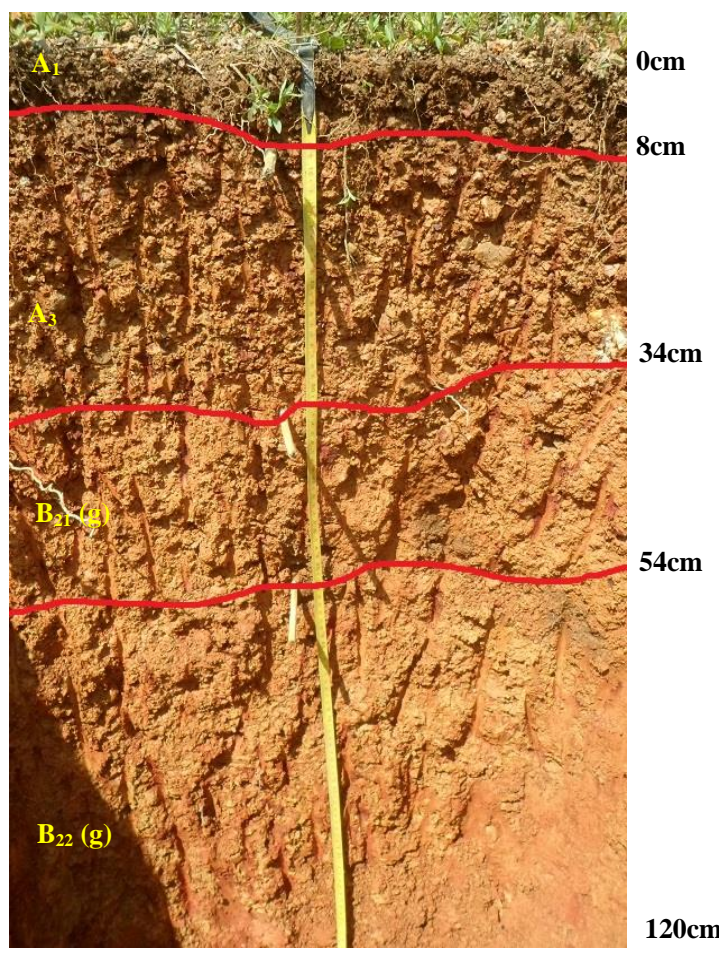

Fig. 4. P1 profile open to the upper slope (Pseudogleyic Plinthic Cambisol). 


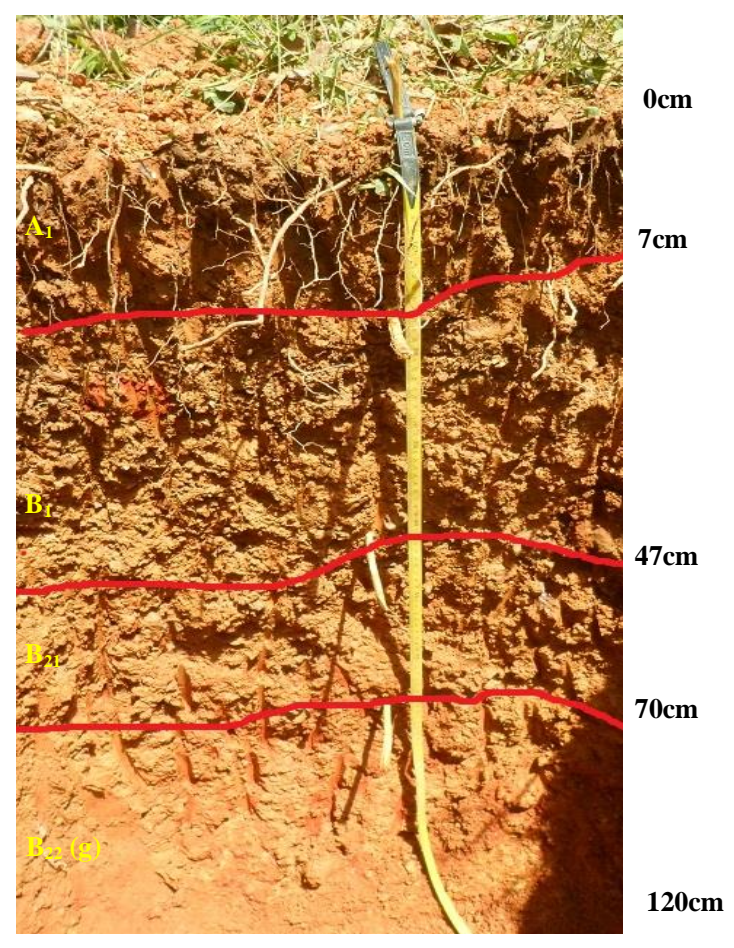

Fig. 5. P2 profile open to the middle slope (Endopseudogleyic Plinthic Cambisol).

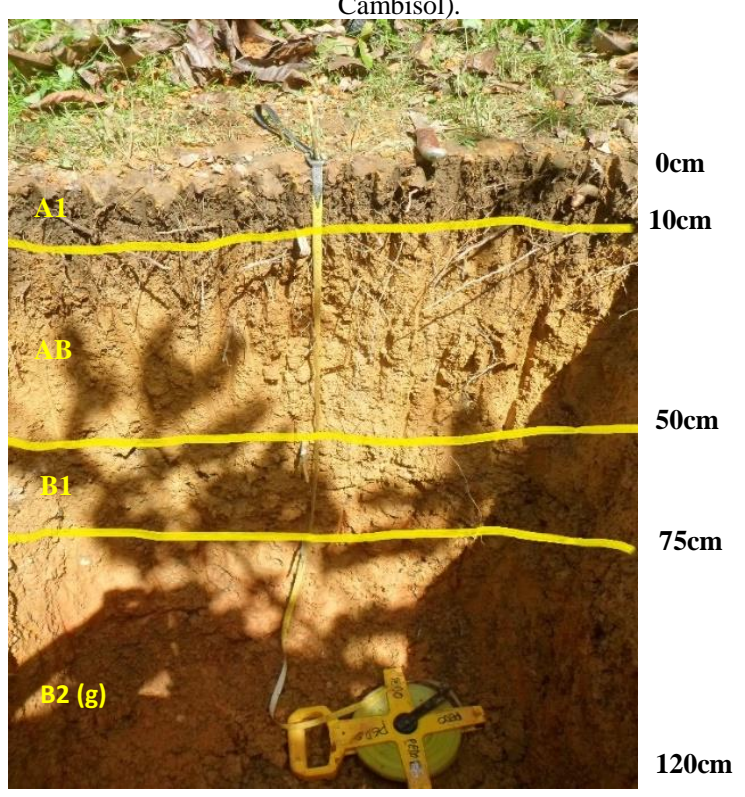

Fig. 7. P4 Profile open to the lower 1/3 slope (Endopseudogleyic Manganiferric Cambisol).

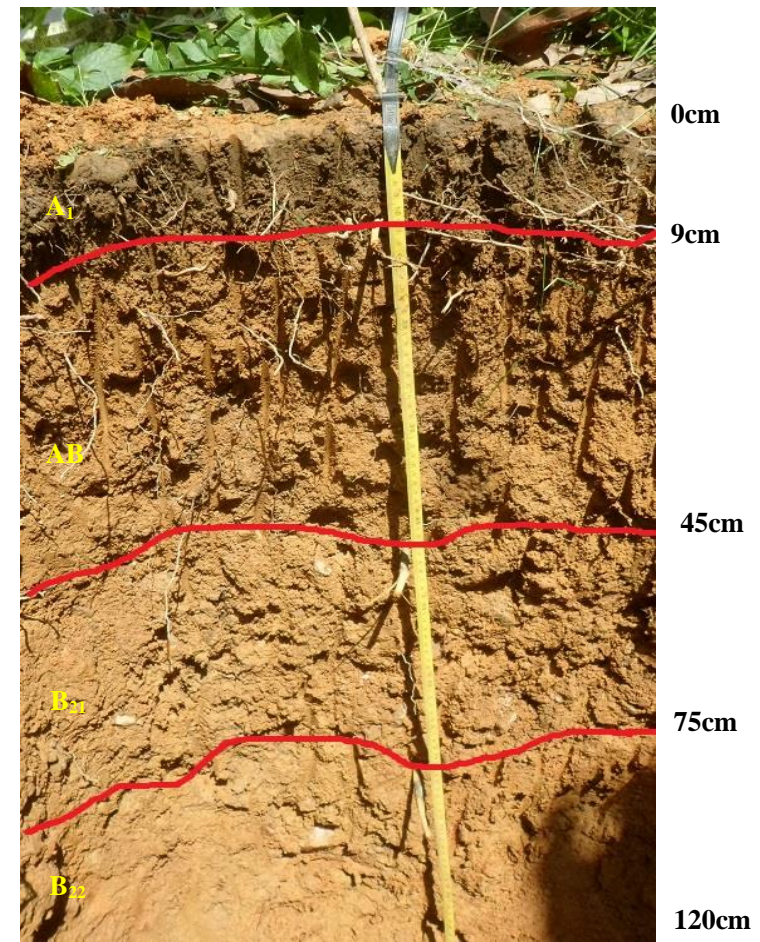

Fig. 6. P3 Profile open to the upper 1/3 slope (Manganiferric Cambisol).

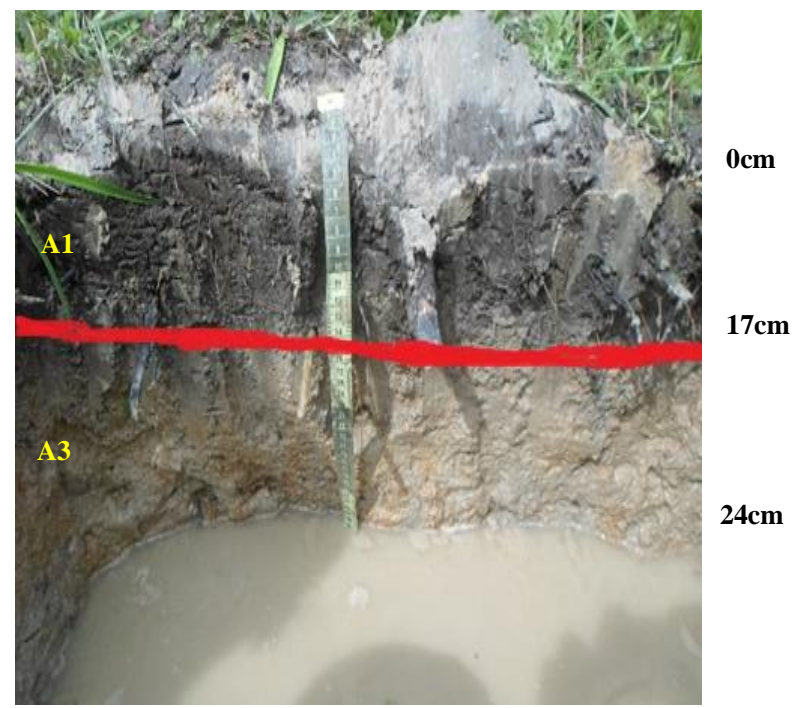

Fig. 8. P5 profile open in the lowland (Colluvic Histic Gleysol).

TABLE I: CONDITION OF COCOA TREES OBSERVED

\begin{tabular}{cccccc}
\hline \hline Sectors & $\begin{array}{c}\text { Total cocoa trees } \\
\text { observed }\end{array}$ & $\begin{array}{c}\text { Number not } \\
\text { degraded }\end{array}$ & $\begin{array}{c}\text { Number } \\
\text { degraded }\end{array}$ & $\begin{array}{c}\text { \% Non-degraded } \\
\text { cocoa trees }\end{array}$ & $\begin{array}{c}\% \text { degraded cocoa } \\
\text { trees }\end{array}$ \\
\hline HV & 280 & 56 & 224 & 20 & 80 \\
MV & 305 & 122 & 183 & 40 & 60 \\
$1 / 3>\mathrm{BV}$ & 315 & 237 & 78 & 75 & 25 \\
$1 / 3<\mathrm{BV}$ & 318 & 255 & 63 & 80 & 20 \\
$\mathrm{BF}$ & 170 & 51 & 119 & 30 & 70 \\
\hline \hline
\end{tabular}

HV: High slope MV: Middle slope 1/3>BV: 1/3 Upper Lowland 1/3<BV: 1/3 Lower Lowland BF: Shallow areas.

Overall, they are deep with a dominant sandy-clay texture, except for the first few horizons which have a sandy-silty to sandy-clay texture. The colours vary from 2.5YR; 5YR; 7.5YR to 10YR, with patches in the red ochre to yellow ochre range. The structure is generally polyhedral and sub-angular.

\section{B. State of Degradation of Cocoa Trees}

Table I shows the distribution of cocoa trees observed by topographic segment and the evaluation of their state of degradation. In the upper slope, $80 \%$ of 280 cocoa trees analysed are degraded. In the middle slope, $60 \%$ of 305 cocoa trees are degraded. In the $1 / 3$ of the lower slope, $25 \%$ of 315 cocoa trees observed are degraded. As for the 80 trees 
observed in the lower $1 / 3$ of the slope, only $20 \%$ are degraded. On the other hand, $80 \%$ are degraded in the lowland area on 30 plants observed.

\section{Granulometry}

The Granulometry of the horizons is shown in Table II. The majority of the soils have a silty-sandy-clay to sandy-silty texture at the surface and a sandy-clay texture at depth. On the whole, they are poor in silt (less than 15\%) beyond a depth of $40 \mathrm{~cm}$. As for the coarse grain, they are very high (EG $>70 \%$ ) in all the profiles.

TABLE II: TEXTURE OF SURVEYED SOILS

\begin{tabular}{|c|c|c|c|c|c|}
\hline Profile & $\begin{array}{l}\text { Horizons } \\
\quad(\mathrm{cm})\end{array}$ & Clay (\%) & Silt $(\%)$ & $\begin{array}{c}\text { Sand } \\
(\%)\end{array}$ & EG (\%) \\
\hline \multirow{4}{*}{$\mathrm{P} 1$} & $0-8$ & 10 & 36.75 & 53.25 & 81.66 \\
\hline & $8-34$ & 11 & 22.35 & 66.65 & 88.53 \\
\hline & $34-54$ & 15.5 & 19.10 & 65.4 & 92.85 \\
\hline & 54-120 & 18.5 & 17.25 & 64.25 & 72.72 \\
\hline \multirow{4}{*}{$\mathrm{P} 2$} & $0-7$ & 9.3 & 48.4 & 44.3 & 66.66 \\
\hline & $7-43$ & 11.5 & 41.3 & 48.2 & 83.32 \\
\hline & $43-70$ & 13.5 & 10.4 & 76.1 & 81.46 \\
\hline & $70-120$ & 22 & 8.3 & 69.7 & 80.45 \\
\hline \multirow{4}{*}{ P3 } & $0-9$ & 8.5 & 47.05 & 44.45 & 42.46 \\
\hline & $9-45$ & 10.2 & 38.65 & 45.15 & 48 \\
\hline & $45-75$ & 15.5 & 7.9 & 76.6 & 55.25 \\
\hline & $75-120$ & 18.35 & 3.4 & 78.25 & 60 \\
\hline \multirow{4}{*}{ P4 } & $0-10$ & 10 & 45.35 & 44.65 & 30.76 \\
\hline & $10-50$ & 12.5 & 38.7 & 48.8 & 50.15 \\
\hline & $50-75$ & 20.5 & 11.3 & 68.2 & 52.75 \\
\hline & $75-120$ & 22 & 6.5 & 73.5 & 43.33 \\
\hline \multirow{2}{*}{ P5 } & $0-17$ & 15.35 & 28.5 & 55.15 & 10.34 \\
\hline & $17-24$ & 29.5 & 16.25 & 53.25 & 20.85 \\
\hline
\end{tabular}

EG: Coarse grain.

\section{Acidity of the Studied Soils}

Fig. 9 and 10 highlight the evolution of $\mathrm{pH}$ of $\mathrm{H}_{2} \mathrm{O}$ and $\mathrm{pH}$ of $\mathrm{KCl}$, respectively depending on the depth. The active acidity, determined by the $\mathrm{pH}$ of $\mathrm{H}_{2} \mathrm{O}$, varies from 4.40 to 5.54 and indicates that the soils are acidic, with a higher acidity at greater depths. As for $\mathrm{pH}$ of $\mathrm{KCl}$, which is the exchange acidity, it varied from 3.68 to 4.17 , with a tendency for the soil to become more acidic at depth, as was the case with $\mathrm{pH}$ of $\mathrm{H}_{2} \mathrm{O}$. The difference between the two varied from 0.98 to 1.60 with a $\mathrm{pH}$ of $\mathrm{KCl}$ lower than the $\mathrm{pH}$ of $\mathrm{H}_{2} \mathrm{O}$.

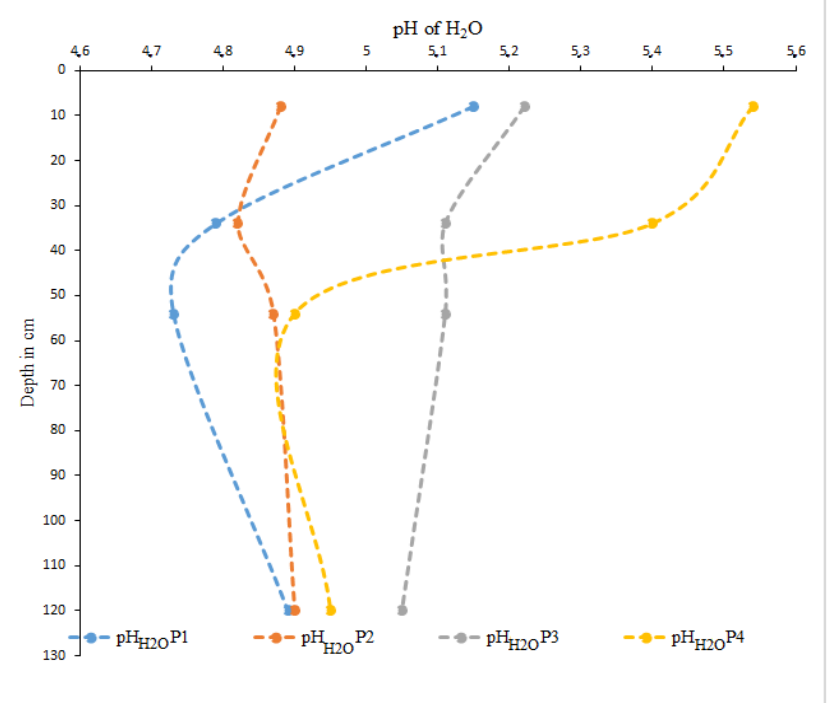

Fig. 9. Variation of water $\mathrm{pH}$ depending on the depth.

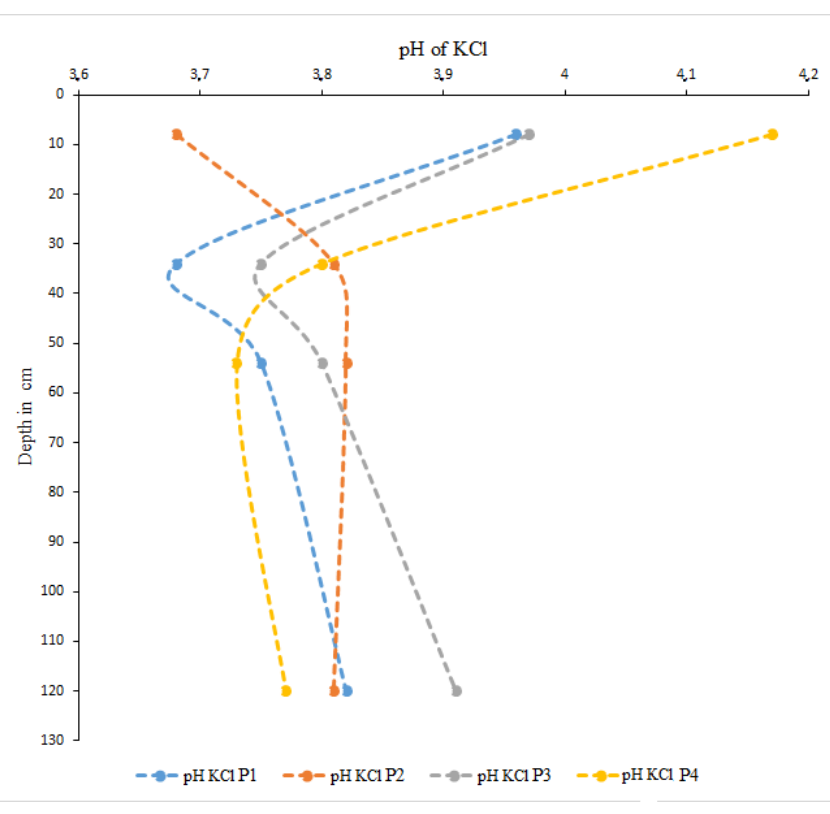

Fig. 10. Variation of $\mathrm{KCl} \mathrm{pH}$ depending on the depth.

E. Organic Matter Content in the Surface part of the Soils (Horizons 0-20cm)

The results presented in Table III indicate that in the 0$20 \mathrm{~cm}$ horizons, the soils studied have a low organic nitrogen content (less than $0.15 \%$ ) and total organic carbon (less than $2 \%$ ) and are relatively poor in organic matter (less than $3.5 \%$ ) from top to bottom. The calculated $\mathrm{C} / \mathrm{N}$ ratio is therefore high and above 12 .

TABLE III: ORGANIC MATTER MESURED AT MESUREÉ A 0-20CM DEPTH

\begin{tabular}{ccccc}
\hline \hline Sectors & $\mathrm{C}(\%)$ & $\mathrm{N}(\%)$ & $\mathrm{MO}(\%)$ & $\mathrm{C} / \mathrm{N}$ \\
\hline HV & 1,97 & 0,12 & 3,40 & 16,42 \\
MV & 0,78 & 0,07 & 1,34 & 11,14 \\
$1 / 3>\mathrm{BV}$ & 0,91 & 0,07 & 1,57 & 13 \\
$1 / 3<\mathrm{BV}$ & 0,95 & 0,03 & 1,64 & 31,67 \\
BF & 1,08 & 0,08 & 1,86 & 13,5 \\
\hline
\end{tabular}

C: organic carbon N: nitrogen MO: organic matter.

\section{F. Determination of Exchangeable bases, Calculation of the CEC and Saturation Rate of the $0-20 \mathrm{~cm}$ Horizons}

On the whole, the soils on the $0-20 \mathrm{~cm}$ horizon are relatively poor in exchangeable bases with very low contents not exceeding $2.25 \mathrm{cmol} / \mathrm{kg}$. $\mathrm{Ca}^{2+}$ contents vary between $0.28 \mathrm{cmol} / \mathrm{Kg}$ and $0.53 \mathrm{cmol} / \mathrm{Kg}, \mathrm{Mg}^{2+}$ contents between 0.17 and $0.25 \mathrm{bcmol} / \mathrm{Kg}$ and $\mathrm{K}^{+}$contents between 0.09 and $0.22 \mathrm{cmol} / \mathrm{Kg}$. In terms of $\mathrm{K}^{+}$, only the bottom soil has a content of over $1.68 \mathrm{cmol} / \mathrm{Kg}$. These soils are highly desaturated to moderately saturated with levels ranging from 8.44 to $43.96 \%$ from the upper slope to the lower slope (Table IV). Indeed, the soils of the upper, middle and lower slopes show a very high desaturation with a rate lower than 15 . Only the lowland soil shows an average saturation $(\mathrm{V}=43.96 \%<50 \%)$. 
TABLE IV: EXCHANGEABLE BASES DOSED IN 0-20CM SOIL HORIZON

\begin{tabular}{ccccccc}
\hline \hline Sectors & $\mathrm{Ca}^{2+}(\mathrm{cmol} / \mathrm{kg})$ & $\mathrm{Mg}^{2+}(\mathrm{cmol} / \mathrm{kg})$ & $\mathrm{K}^{+}(\mathrm{cmol} / \mathrm{kg})$ & $\mathrm{Na}^{+}(\mathrm{cmol} / \mathrm{kg})$ & $\mathrm{CEC}(\mathrm{cmol} / \mathrm{kg})$ & $\mathrm{V}(\%)$ \\
\hline $\mathrm{HV}$ & 0.529 & 0.248 & 0.116 & 0.07 & 11.41 & 8.440 \\
$\mathrm{MV}$ & 0.443 & 0.165 & 0.074 & 0.082 & 7.5 & 10.187 \\
$1 / 3>\mathrm{BV}$ & 0.283 & 0.168 & 0.216 & 0.076 & 6.2 & 11.984 \\
$1 / 3<\mathrm{BV}$ & 0.366 & 0.157 & 0.089 & 0.094 & 5.4 & 13.074 \\
$\mathrm{BF}$ & 0.281 & 0.173 & 1.684 & 0.104 & 5.1 & 43.961 \\
\hline \hline
\end{tabular}

\section{G. Cation Balance Ratios}

The values of cation balance ratios are recorded in Table V. For the $\mathrm{Ca}^{2+} / \mathrm{Mg}^{2+}$ ratio, the highest value is observed in the middle slope, while the lowest is in the lowland. For the $\mathrm{Mg}^{2+} / \mathrm{K}^{+}$ratio, the values range from $0.78<\mathrm{Mg}^{2+} / \mathrm{K}^{+}<2.23$ in the upper to lower slope soils, in contrast to the values in thelowland below 0.5 . The $\mathrm{Ca}^{2+} / \mathrm{K}^{+}$ratio on this site is very low ( 0.17 to 5.99$)$ and only on the middle slope does it approach 6. As for the $\mathrm{K}^{+} /\left(\mathrm{Ca}^{2+}+\mathrm{Mg}^{2+}\right)$ and $\mathrm{K}^{+} / \mathrm{CEC}$ ratios, the values are very low $\left(\mathrm{K}^{+} /\left(\mathrm{Ca}^{2+}+\mathrm{Mg}^{2+}\right)<2\right.$ and $\mathrm{K}^{+} / \mathrm{CEC}<$ $30 \%)$ in the soils from the upper to the lower slopes. In contrast, they are high $\left(\mathrm{K}^{+} /\left(\mathrm{Ca}^{2+}+\mathrm{Mg}^{2+}\right)>2\right.$ and $\mathrm{K}^{+} / \mathrm{CEC}$ $>30 \%$ in the lowland soils.

TABLE V: CATION BALANCE RATIOS

\begin{tabular}{cccccc}
\hline \multicolumn{6}{c}{ TABLE V: CATION BALANCE RATIOS } \\
\hline \hline $\mathrm{Ca}{ }^{2+} / \mathrm{Mg}^{2+}$ & $\mathrm{Mg}^{2+} / \mathrm{K}^{+}$ & $\mathrm{Ca}^{+} / \mathrm{K}^{+}$ & $\begin{array}{c}\mathrm{K} /\left(\mathrm{Ca}^{2+}+\right. \\
\left.\mathrm{Mg}^{2+}\right)\end{array}$ & $\mathrm{K}^{+} / \mathrm{CEC}$ \\
\hline $\mathrm{HV}$ & 2.133 & 02.138 & 4.56 & 0.15 & 0.01 \\
$\mathrm{MV}$ & 2.685 & 2.230 & 5.99 & 0.12 & 0.01 \\
$1 / 3>\mathrm{BV}$ & 1.685 & 0.778 & 1.31 & 0.48 & 0.03 \\
$1 / 3<\mathrm{BV}$ & 2.331 & 1.764 & 4.11 & 0.17 & 0.02 \\
$\mathrm{BF}$ & 1.624 & 0.103 & 0.17 & 3.71 & 0.33 \\
\hline \hline
\end{tabular}

H. Influence of $p H$ and Coarse Grains (EG) on the Development of Cocoa Trees

The relationship between the state of degradation of cocoa trees reveals that for $\mathrm{pH}$ values $<5$, there are more degraded cocoa trees than non-degraded ones. On the other hand, at $\mathrm{pH}>5$, there are more non-degraded cocoa trees than degraded ones (Fig. 11). Compared to the levels of coarse grain, cocoa trees are more degraded at percentages above 50 . This is the case on the upper and middle slopes with $80 \%$ of cocoa trees degraded. On the other hand, on the lower slopes, the rate of coarse grains being less than $50 \%$, the state of degradation of cocoa trees is low (Fig. 12).

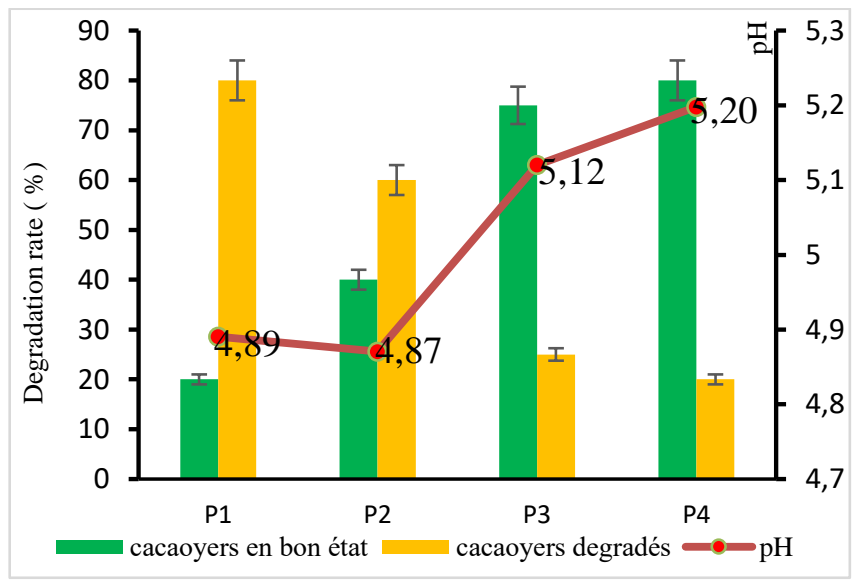

Fig. 11. Influence of $\mathrm{pH}$ on cocoa trees development.

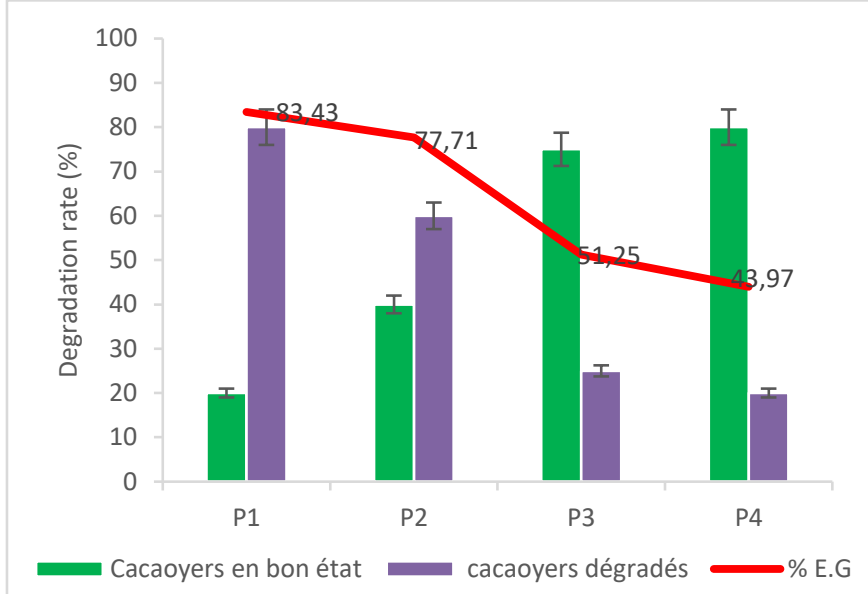

Fig. 12. Influence of EG on cocoa trees development.

\section{Correlations between pH, Exchangeable Bases and Organic Matter}

Table VI presents the correlative studies between $\mathrm{pH}$, exchangeable bases, nitrogen and organic matter. The results indicate that there is a significant correlation between $\mathrm{Ca}^{2+}$ and $\mathrm{C} / \mathrm{N}$ at $\mathrm{P}=0.02$ and less significant between $\mathrm{pH}$ and $\mathrm{K}^{+}$at $\mathrm{P}=0.08$.

TABLE VI: CORRELATION BETWEEN DOSED ELEMENTS

\begin{tabular}{ccccccccc}
\hline Variables & $\mathrm{H}_{2} \mathrm{O} \mathrm{pH}$ & $\mathrm{N}$ & $\mathrm{K}^{+}$ & $\mathrm{Ca}^{2+}$ & $\mathrm{Mg}^{2+}$ & $\mathrm{Na}^{+}$ & $\mathrm{C} / \mathrm{N}$ & $\mathrm{MO}$ \\
\hline $\mathrm{H} 2 \mathrm{O} \mathrm{pH}$ & 1.00 & & & & & & & \\
$\mathrm{~N}$ & -0.70 & 1.00 & & & & & & \\
$\mathrm{~K}^{+}$ & $\mathbf{0 . 0 8}$ & 0.12 & 1.00 & & & & & \\
$\mathrm{Ca}^{2+}$ & -0.51 & 0.51 & -0.56 & 1.00 & & & & \\
$\mathrm{Mg}^{2+}$ & -0.43 & 0,88 & -0.14 & 0.71 & 1.00 & & & \\
$\mathrm{Na}^{+}$ & 0.50 & -0.52 & 0.74 & -0.61 & -0.59 & 1.00 & & \\
$\mathrm{C} / \mathrm{N}$ & 0.84 & -0.61 & -0.27 & $\mathbf{0 . 0 2}$ & -0.18 & 0.28 & 1.00 & \\
$\mathrm{MO}$ & -0.23 & 0.79 & -0.07 & 0.65 & 0.98 & -0.46 & 0.00 & 1.00 \\
\hline
\end{tabular}

\section{DISCUSSION}

The soils highlighted in this study show plinthic, manganiferric, endo and pseudogleyic character in the upper and middle slope topographic positions, while in the lower slope the character is colluvic. These Cambisols appear similar to those studied by [23] in the same area. All the topographical positions are subject to exploitation, as explained by [10], leading to an extension by the farmers until the available land is exhausted. Moreover, the cocoa trees in some of these positions are degraded, leaving the place to abandoned surfaces, transformed into fallow land or reconverted into food crops [9]. The soils studied are characterised by a high rate of coarse grains and poor drainage on the upper and middle slopes, and the opposite on the lower slopes. They thus reveal the influence of topography in their distribution. According to [24], this 
influence is manifested by the shape of the relief, erosion, leaching and hydromorphy.

The abundance of coarse grains (EG>50\%) is the main morphological constraint of the soils of the upper and middle slopes. This is in line with [25] who, in their study in the south-western region of Côte d'Ivoire, pointed out that coarse grains are frequently observed on these topographic positions. Furthermore, [26], [27], indicate that coarse grains with a weight rate above $50 \%$ considerably reduce the water in the soil, as well as the volume of usable soil. And, according to [5], coarse grains, when contained in a horizon whose thickness is greater than $25 \mathrm{~cm}$, can modify the trajectory, change the appearance or stop the growth of the taproot of the cocoa tree leading to an early mortality (at 2 years) of around $13 \%$ on soils with little or no gravel and $53 \%$ on soils with a lot of gravel [28].

Soil depths greater than $120 \mathrm{~cm}$ on the upper and middle slopes would be a good criterion for cocoa production as indicated by [29]. However, [25] showed that the upper and middle slopes are unfavourable for cocoa production in the southwest of Côte d'Ivoire because of induration phenomena that are observed at less than one metre.

The soils studied in the high and medium slopes are poorly drained, characterised by the presence of hydromorphy, which is a parameter of cocoa tree degradation, as underlined by [6] who noted it in the Centre-West of Côte d'Ivoire on the same topographic positions. In fact, the cocoa tree is very sensitive to prolonged excess water, causing redox phenomena, a source of asphyxiation [30]. Studies have also shown that prolonged and excessive humidity in the soil has a negative effect on the development of the cocoa tree [31]. Also, according to [32], hydromorphy or excess water decreases the availability of oxygen for plants in the soil, which can lead to the cessation of growth and then the death of cocoa trees.

The soils studied are acidic $(\mathrm{pH}<5.8)$ and this acidity is probably not only due to $\mathrm{H}+$ protons but could also be due to acidifying ions such as $\mathrm{Al}^{3+}, \mathrm{Fe}^{3+}, \mathrm{Mn}^{2+}$ which, in addition to acidification, can cause aluminous, ferrous or manganic toxicity. According to [33], at acid $\mathrm{pH}$, nitrification, phosphorus deficiency, aluminium or manganese toxicity and the availability of certain heavy metals are reduced in the soil. One could therefore attribute the drop in yields and the degradation of cocoa trees encountered at Koffikro-Affema on the basis of this information, especially since [34] in Ghana and [35] in Togo, emphasise that cocoa trees experience a considerable drop in yield and even mortality of young plants on soils with an acidic $\mathrm{pH}$ (4.5 to 6), corresponding to the $\mathrm{pH}$ of the soils studied.

According to [7], cocoa crops require a minimum of $3.5 \%$ organic matter in the first $15 \mathrm{~cm}$. However, this is not the case for the soils studied, because on the toposequence, the soils are moderately poor in organic matter and have a high $\mathrm{C} / \mathrm{N}$ ratio, with a low organic carbon and nitrogen content from the top to the bottom of the slope. According to [36], this reflects a slow decomposition of organic matter. This low mineralisation activity of soil organic matter can be linked, on the one hand, to the acidity of the soil which inhibits nitrification and limits mineralisation [37], [38] and, on the other hand, to the sandy texture of the soil which limits the proliferation of microorganisms and those involved in the mineralisation of organic matter. The sum of exchangeable bases is low in the studied soils. [7] made the same observation and indicated that soils under cocoa trees in the south-west of Côte d'Ivoire have a low sum of exchangeable bases. These soils are strongly desaturated to moderately saturated $(\mathrm{V}<50 \%)$ corroborating [39] who estimated that moderately or strongly desaturated soils are highly represented in tropical areas with saturation rates between 20 and $60 \%$. It thus constitutes a constraint to cocoa farming, since according to [40], a saturation rate of less than $60 \%$ is a factor of nutritional imbalance for cocoa trees. CEC levels between 5.1 and $11.41 \mathrm{cmol} / \mathrm{kg}$ are insufficient to initiate the optimal development of cocoa trees, because as noted by [40], the minimum level should be $12 \mathrm{cmol} / \mathrm{kg}$. Also, according to [23], the low CEC content of a soil is not without consequences on the mineral nutrition of the cocoa tree, which could experience problems of iron toxicity.

$\mathrm{Ca}^{2+}$ values between 0.281 and $0.529 \mathrm{cmol} / \mathrm{kg}$ are low. For [33], exchangeable calcium deficiencies normally occur in soils with low $\mathrm{CEC}$ and $\mathrm{pH} \leq 5.5$, which is the case of the studied plot. For $\mathrm{Mg}^{2+}$, the levels are 0.157 to $0.248 \mathrm{cmol} / \mathrm{kg}$, below the threshold value $0.5 \mathrm{cmol} / \mathrm{kg}$ indicated for tropical regions by [41]. These soils are therefore deficient in magnesium, especially since the $\mathrm{Mg}^{2+} / \mathrm{K}^{+}$ratio is less than 3, which shows that they are magnesium deficient [29]. The $\mathrm{Ca}^{2+} / \mathrm{Mg}^{2+}$ ratio lower than 3 indicates an imbalance, reducing phosphorus uptake and therefore a phosphorus deficiency for the soils studied. These results corroborate those of [7], which showed that all soils under cocoa trees in the southwest of Côte d'Ivoire have deficits in assimilable phosphorus. Thus, the soils of Koffikro-Affema are deficient in $\mathrm{Ca}^{2+}$ and $\mathrm{Mg}^{2+}$ predisposing the cocoa trees to early degradation (disease), thus agreeing with [42] who stated that cocoa trees deficient in $\mathrm{Ca}^{2+}$ and $\mathrm{Mg}^{2+}$ are less resistant to pod rot. According to [43], the threshold value for $\mathrm{K}^{+}$is $0.2 \mathrm{cmol} / \mathrm{kg}$, whereas the soils studied are below this. There is therefore $\mathrm{a} \mathrm{K}^{+}$ deficiency, especially on the upper and middle slopes and on the lower $1 / 3$ of the lower slopes.

\section{CONCLUSION}

The study conducted in a cocoa farm in Koffikro-Affema made it possible to determine the morphological and chemical characteristics of the soils in this locality. This study highlighted the morphological constraints to cocoa farming, which are: (1) poor internal drainage, (2) the high load of coarse grains on the upper and middle slopes, and chemical constraints, namely: (3) acidic $\mathrm{pH}$, (4) low organic matter content, (5) absorbent complex characteristics and unfavourable chemical balances. The study also showed that there is a relationship between the topographic position and the degradation of the cocoa trees, more marked on the higher parts of the slope than on the lower parts and that at the level of $\mathrm{pH}$, when it is less acidic (low), the CEC value is low. Similarly, when the $\mathrm{pH}$ is more acidic (high), the availability of nutrients such as calcium and magnesium is reduced. Thus, the constraints to the development of cocoa trees in this locality are not only linked to certain physical properties of the soil, but also that the degradation of cocoa trees is dependent on the topography. As a result, the soils of the 
lower slopes are the most favourable for cocoa production in Koffikro-Affema.

\section{REFERENCES}

[1] Freud E., Petithuguenin P., Richard J., Les champs du cacao. Un défi de compétitivité. Afrique-Asie, Ed. Karthala-Cirad, 216 p, 2000.

[2] Assiri A. A., Kacou E. A., Assi F. A., Ekra S., Dji K. F., Couloud J. Y., Yapo A., R., Rentabilité économique des techniques de réhabilitation et de replantation des vieux vergers de cacaoyers (Théobroma cacao L.) en Côte d'Ivoire. Journal of Animal \& Plant Sciences, 14(2):1939$1951,2012$.

[3] ICCO, International Cocoa Organization. QBCS, Vol. XLII No. 1, Cocoa year 2016/17, 5 p, 2017.

[4] Koko L. K. Influence des caractères morpho pédologiques et chimiques des sols sur la dégradation précoce des cacaoyers dans le Sud-Ouest de la Côte d'Ivoire. Thèse de Doctorat Unique de l'Université de CocodyAbidjan, Côte d'Ivoire, 148 p, 2008.

[5] Kassin K. E. Etude des conditions pédoclimatiques pour la replantation cacaoyère dans le Centre-Ouest de la Côte d'Ivoire: cas des départements de Divo et de Gagnoa. Thèse de Doctorat Unique de l'Université d'Abidjan-Cocody, pp. 10-45, 2009.

[6] Kassin K. E., Yoro G. R., Koko L. K., N'Goran K. E., Yao-Kouamé A. Sols favorables à la cacaoculture au Centre-Ouest de la Côte d'Ivoire dans un contexte d'assèchement climatique. Int. J. Biol. Chem. Sci. 6(3): pp. 1148-1157, 2012.

[7] Koko L. K., Yoro R. G., N'Goran K., Assa A. Evaluation de la fertilité des sols sous cacaoyers dans le Sud-Ouest de la Côte d'Ivoire. Agronomie Africaine, XX (1): 81-95, 2008.

[8] Konaté Z., Assiri A.A., Messoum F. G., Sekou A, Camara M., YaoKouamé A. Contraintes de la replantation cacaoyère en Côte d'Ivoire. Science de la vie, de la terre et agronomie rev. cames, 04(2), 7p, 2016.

[9] Aguilar P., Paulin D., N'kamleu G., Raillard A., Deheuvels O., Petithuguenin P., Gockowski J. L'évolution des vergers de cacaoyers en Côte d'Ivoire entre 1995 et 2002. The 14th International Conference on Cocoa Research, Cocoa Producer's Alliance, Accra (Ghana), pp. 6296, 2003.

[10] Assiri A. A. Identification des pratiques paysannes dans la conduite des vergers de cacaoyers en Côte d'Ivoire. Mémoire DEA, Université de Cocody-Abidjan, 54 p., 2007.

[11] Hauhouot C. Les pressions anthropiques sur les milieux naturels du sud-est ivoirien Human pressure on natural environment in South-East Ivory-Coast. Geo-Eco-Trop, 28, 1-2: 69-82, pp.1-14, 2004.

[12] Koua A. H. G. Situation de la production de café en Côte d'Ivoire: cas du département d'Aboisso. Mémoire de fin d'étude pour l'obtention du diplôme d'agronomie approfondie. 2007.

[13] Gbocho O. D. Conséquences physiques et socio-économiques de la dégradation de la forêt à Aboisso. Thèse unique de Doctorat Université Félix Houphouët Boigny de Cocody, 2015.

[14] Guillaumet J.L., Adjanohoun E. La végétation de la Côte d'Ivoire, pp.1-12, 1971.

[15] Yao Kouadio A. F., Salze D., Lasm T., Koffi Y. B., Belcourt O., LopezFerber M., Ahoussi K. E., Youan Ta M. Cartographie de la vulnérabilité à la pollution des aquifères dans une zone minière : cas de la mine d'or d'Afema (Sud-est de la Côte d'Ivoire). International Journal of Innovation and Applied Studies, 17(2), 682-685, 2016.

[16] Beaudou A. G., Chatelin Y. Méthodologie de la représentation des volumes pédologiques: typologie et cartographie dans le domaine ferralitique africain. Cahiers ORSTOM, Série Pédologie, 15 (1): 3-18, 1977.

[17] Baize D., Jabiol B. Guide pour la description des sols. INRA, 375 p., 1995.

[18] WRB. Base de Reference Mondiale des sols: classification des sols. 230 p, 2014.

[19] Mathieu C., Pieltain F. Analyse chimique des sols méthodes choisies. Editions Tec et Doc/Lavoisier, Paris, 408 p, 2003.

[20] Walkley A., Black I. A. An Examination of Degtjareff Method for Determining Soil Organic Matter and a Proposed Modification of the Chromic Acid Titration Method. Soil Sciences. 37: 29-37, 1934.

[21] Nelson D. W., Sommer L. E. Total carbon, organic carbon, and organic matter. In A.L. Page (ed.) Methods of Soil Analysis. 2nd Ed. ASA Monogr. 9(2). Amer. Soc. Agron. Madison, WI. pp. 539-579., 1982.

[22] Metson, A.J. Methods of chemical analysis for soil survey samples. NZ Soil Bur Bull, 12: 12-14, 1956.

[23] N'Guessan K. J-C., Akotto O. F., Snoeck D., Camara M., Yao-Kouamé A. Potentiel de fertilité chimique des vergers de cacaoyer theobroma cacao 1. (malvacea) en Côte d'Ivoire. International Journal of Innovation and Applied Studies, 18(3): 868-879, 2016.
[24] Yoro G. La pédologie pour une gestion durable des sols. Cours d'initiation pour les agents des caisses de stabilisation et de péréquation du Gabon. Abidjan: Centre National de Recherche Agronomique (CNRA), 24 p, 2002.

[25] Koko L. K., Kassin K. E., Yoro G., N'Goran K., Assiri A. A., YaoKouamé A. Corrélations entre le vieillissement précoce des cacaoyers et les caractéristiques morphopédologiques dans le sud-ouest de la côte d'ivoire. Journal of Applied Biosciences 24: 1508-1519, 2009.

[26] Wessel M. Fertilizer requirements of cacao (Theobroma cacao L.) in south western Nigeria. Publ. royal Trop. Inst. Amsterdam, $\mathrm{N}^{\circ} 61,104 \mathrm{p}$, 1971.

[27] Boa D. Caractérisation, propriétés hydrodynamiques, contraintes et potentialités des sols gravillonnaires: cas de Booro-Borotou, région de Touba, Nord-Ouest de la Côte d'Ivoire. Thèse de Doctorat Ingénieur, Université d'Abidjan, 134 p., 1989.

[28] Jagoret P., Jadin P. Recherche d'un itinéraire technique pour la replantation des cacaoyères au Togo. IV. Contribution à une meilleure approche pédologique de la replantation cacaoyère. Café Cacao Thé, 37(4):313-320., 1993.

[29] Mossu G. Le cacaoyer. Collection Le technicien d'agriculture tropicale. Éditions Maisonneuve et Larose, Paris, France, pp. 1-70, 1990.

[30] Yoro G. Formation à la reconnaissance des sols à cacaoyers et aux techniques de régénération cacaoyère. Atelier de formation des techniciens supérieurs, projet STCP, Convention CNRA-STCF, 9p, 2004.

[31] Verliere G. Influence de l'humidité du sol sur le développement du cacaoyer. Café-cacao Thé, 10(4): pp. 265-274, 1970.

[32] Vilain M. La Production Végétale: la Maîtrise Technique de la Production (2 $2^{\text {ème }}$ éd). Lavoisier TEC\&DOC: Paris, pp. 5-45, 1997.

[33] Landon J. R. Booker tropical soil manual. A handbook for soil survey and agricultural land evaluation in the tropics and subtropics. Oxon, UK: Longman, 120 p, 1991.

[34] Appiah M. R., Ofori-Frimpong K., Afrifa A. A., Abekoe M. K., Snoeck D. Improvement of soil fertility management in cocoa plantations in Ghana. FSP Regional Cacao scientific and technical final report. CRIG (Cocoa Research Institute of Ghana), Ghana, 22 p, 2006.

[35] Tossah B. K., Koudjega T., Snoeck D. Amélioration de la gestion de la fertilité des sols dans les plantations de cacaoyers au Togo. Rapport final scientifique et technique du FSP Régional Cacao. ITRA/CRAF, Togo, 43 p, 2006.

[36] Duprargue A., Pigalle P. Composition des M.O et turn over: rôles et fonction des MO. Actes du colloque "Gestion de l'état organique des sols", Agrotransfert, 41 p, 2011.

[37] Amlinger F., Gôtz B., Dreher P., Geszti J., Weisstiner C. Nitrogen in biowaste and yard waste compost: dynamics of mobilisation and availability-a review. European Journal of Soil Biology, 39: 107-116, 2003.

[38] Kende S. Minéralisation de l'azote dans deux sols amendés avec deux composts enrichis d'un antibiotique. Maîtrise en Microbiologie agroalimentaire, Université Laval, 76p, 2010.

[39] Boyer J. Les sols ferrallitiques. Facteurs de fertilité et utilisation des sols. Doc. Tech., N52, Orstom, 384 p, 1982.

[40] Smith A. J. Soils classification and the cocoa grower. Cocoa Growers' Bull. 30 (5): 5-10, 1980.

[41] Mbonigaba J.J.M., Nzeyimana I., Bucagu C., Culot M. Caractérisation physique, chimique et microbiologique de trois sols acides tropicaux du Rwanda sous jachères naturelles et contraintes à leur productivité Biotechnol. Agron. Soc. Environ., 13 (4): 545-558, 2009.

[42] Tarjot M. Nouvelle contribution à l'étude de la pourriture des cabosses du cacaoyer due au Phytophthora palmivora (Butl.) en Côte d'Ivoire. Café, Cacao, Thé, 15 (1), 31-48, 18 p, 1971.

[43] Voundi N. JC. Utilisation des déchets de l'industrie du bois en vue de l'amélioration de la fertilité chimique des sols acides tropicaux. Thèse de doctorat: Université de Gand (Belgique), 1998. 